\title{
Scott Ross, VFX manager
}

Scott Ross started his career in 1988 as a general manager at Industrial Light \& Magic (ILM), one of the pioneers of computer-generated visual effects. In 1993 he cofounded Digital Domain, another industry leader, with James Cameron and Stan Winston. These days Ross produces films, teaches, and advocates for the creation of a VFX trade association. Here he recounts the origins of Digital Domain, the challenges that confront VFX shops, and the prospects for industry reform.

\section{How did you get started in the industry?}

I happened to arrive at ILM when digital was just emerging, and we ended up reorganizing the company. It was sort of a perfect storm. I was coming out of video postproduction, where so many things were digital already: film-to-tape transfers, flying spot scanners, and paint boxes. But when I got to ILM, everything was still optical, and because it was optical, things were very slow. I was shocked at how dumb everything was. For example, you had to send film to the lab and wait three days before you got it back and then you'd look at it? And then maybe you had to shoot it all over again? Really?! So it was the perfect storm of me being there and connecting with guys who were incredibly bright, like John Knoll, Dennis Muren, and Scott Squires. We embraced this new technology that allowed us to manipulate images in the digital realm.

Tell us about the evolution of Digital Domain.

The Bay Area in the early 1990s was entrepreneurial heaven. Everybody who was anybody was starting a company. I was running ILM and had a team around me 
with some of the greatest creative people and winners of multiple Academy Awards. And yet our owner was basically not there. He was an absentee landlord. In the five or so years that I ran the company, I only met George Lucas three or four times.

At that point, ILM was carrying the rest of Lucasfilm. We had turned a company that was unprofitable into a company that was mildly profitable. We turned a company that was lost in the doldrums of technology to a leading-edge company. The guys (and they were all men) who were working with me at the time were all about my age. They all thought, "Why are we working for George? He's never here. It's not like he's making movies anymore. It's not like we're here for Star Wars. So what are we doing?" And I said, "Let's have a leveraged buyout, a management buyout. George always talks about how he hates all of these services and that the overhead on Skywalker Ranch is too expensive. Let's put together a financial package and make George an offer he can't refuse."

Unfortunately, he refused it. And then I was out because from George's perspective I had gone behind his back to buy his company. I was persona non grata. It was unbearable. So I decided to start my own company, and that's how Digital Domain came about.

I had written a business plan, and then out of the blue I got a phone call from James Cameron, with whom I had worked on The Abyss (1989) and Terminator 2: Judgment Day (1991). Jim had heard that I was starting this company and asked if he could be part of it. I went to my then-wife and asked, "What do you think?" The concept of bringing in another powerful director, having just left George, didn't sit real well with me. She said, "If you start this company and it is just you, you're going to have a difficult time of it. But if you start the company with Jim Cameron's name attached, everybody's going to want to come work for you, because if you work on a Jim Cameron movie, you win an Academy Award." I thought long and hard about it and realized she was right. I always felt that Jim looked up to George. If George had ILM, then Jim needed his own version of ILM, right? And Jim was very excited about it. I said, "Let's have a meeting," and flew down to Burbank, where his company was at the time.

Unexpectedly, Stan Winston, the most celebrated makeup effects guy in the world, showed up at the meeting. It turned out that Jim and Stan were very close friends, so Jim felt that Stan should be part of the company as well. So I flew down to Burbank thinking, "I'm not sure," and I left thinking, "Okay, I've got two partners, Jim and Stan." And that's how Digital Domain was born.

What were the projects that helped to build Digital Domain's reputation?

In 1994 we got True Lies, which was Cameron's movie, and that put us on the map. We were even nominated for an Academy Award for it. We also won the Golden Lion Gran Prix Award for a Budweiser commercial. We even won an MTV Music 
Video Award for "Love Is Strong" with the Rolling Stones. That was a big year, and we became the most talked-about VFX studio in L.A.

Then Titanic (1997) came along, which was a great project but a financial nightmare for you. Can you walk us through that story? It seems to encapsulate the challenges facing the VFX industry.

Let's leave the Titanic realm for a second and establish a few things. The production of visual effects is as amorphous and strange as you can get. Even the people in it don't fully understand it. It's more an art than a science. It changes and morphs. To be a production person, or a director, and truly understand how visual effects work is almost impossible. It's sort of like going to a brain surgeon if you're a podiatrist and saying, “So, we're both doctors. Let's talk!” It's very, very different. It's very complicated and has a ton of moving parts.

This means that when you budget visual effects, it's a best-guess scenario. In Hollywood, with almost everything that is budgeted, the people in charge of making the decisions are always interested in the deal, less so the actual price. It's a hard thing to get your head around, but if you don't know what something costs and I tell you it costs $\$ 100$ but I'm going to give it to you for $\$ 75$, you will want it for $\$ 60$. That's how pricing in Hollywood works. The answer to any bid is, "It's too much!" Now, do they know? No. No idea. But it's always too much.

That became the case even with my partner, Jim, because he put together an agreement with Digital Domain that basically said that he doesn't have control over where the VFX work on his movies gets done. He can suggest to the film studio he's working with that they choose Digital Domain. He can strongly suggest it. But at the end of the day, it's not his money. It's 20th Century Fox's money. So 20th Century Fox ultimately makes the determination on where the work is going to go. So while Digital Domain was saying, "We're going to enter into an agreement with you, a services agreement. You've got to bring the work to us," his response was, "I can't guarantee it. I'll do the best I can."

In return for "best efforts," he got a significant discount off of what our normal price would be. Going into True Lies, it was a brand-new company, and we're pulling in people from all over the world, and at times running around like chickens with our heads cut off. It was a disparate group of people coming together to work on very high-profile projects. It was like the all-star team figuring out how to play together.

So we're working on True Lies with Jim, but we're getting the typical response one expects from a producer or director: "I don't trust my effects company; I want a better deal; you're not doing it right. We're not gonna pay you." On several occasions Digital Domain was almost forced to miss payroll because we were depending on cash flow coming from 20th Century Fox. But the producer and the 
director, who's also the chairman of the board of the company, is saying, "We're not paying you because the work's not done!" I said, "You have to trust me. The work is going to get done. We'll get there." And, lo and behold, the work gets done and in the end we were nominated for an Academy Award. But it was a brutal process.

Fast forward to Titanic. The studio, 20th Century Fox, already had some difficult experiences with Cameron, in that every time he does a movie he goes well over budget, so they were very pleased that Jon Landau, their head of production, took the project because he knew more than anyone at the studio about how movies are actually made. Jim and Jon put together a budget for Titanic somewhere in the low hundred-million-dollar range and unbeknownst to me, they put together a visual effects budget of around \$18 million. But when we took a look at the project, our budget ended up around $\$ 27$ million. So I went back to Jim and said, "We can't do it for \$18 million." And the response from Jim was, "If you don't do it, I'll take it to ILM. They'll do it for that amount." Remember, he was not obliged to bring the work to us.

At the time, ILM's biggest competitor was Digital Domain. ILM's general manager thinks, "The guy who once ran my company is now running my competition and if I can do a movie with Jim Cameron and Jim Cameron can't afford his own company, then I can put a nail in the coffin of my major competitor." How much is that worth? And if ILM can manage the process so that maybe the budget starts off at \$18 million dollars, but finishes up around \$25 million, then ILM only loses $\$ 2$ million. For $\$ 2$ million he can put his only significant competitor out of business.

It's one of these things. If I don't take the work, I'm out of business. And if I do take the work, I might be out of business. So I go to my board of directors and tell them what's going on and they say, "You're between a rock and a hard place. You have to take the work." And I said, "Okay, as long as you know it." So we took the work and then in typical Jim fashion, he had a reality distortion problem. I'd ask him, "Where's your film? Where's the stuff?" Hedd reply, "I'm still shooting," which was a big problem for us because it was crimping our production schedule. Finally I went to Jim and said, "Listen, we're not going to make your July release date." His response: "Well, I'm taking some of the work to ILM and to VIFX." I said, "You have to do what you have to do, but we're not going to make the release date. And it's your problem." And he says, "Just get it done!"

This forces us into major overtime and we're burning through cash like crazy. Normally in an overtime situation I would have the ability to go back to the studio and say, "Guys, your director has put us into overtime. He did not deliver his footage on the date he said he was going to deliver it. Here's a change order." But Jim, the director-producer of Titanic and the chairman of the board of Digital Domain, says, "I won't let you do that. We have an operating committee comprised of me, Stan, and you, and we make those decisions." The decision by a two-to-one vote of the operating committee was that Digital Domain cannot 
go back to the studio for change orders! Needless to say, we were screwed, and quickly moving toward insolvency.

Of course we miss the delivery date, which makes us look like fools because Jim's saying the reason we missed it is because Digital Domain fucked up. In fact, the reason we're missing the delivery date is because he hasn't delivered the footage, but I can't go to the studio and tell them that's what's going on. So I'm just sitting there, powerless, watching us burn through cash. On top of that, we lose part of the work to ILM and VIFX, which means it's no longer solely our movie.

In the end, it worked out great for Jim. Had he delivered on July 2, Titanic would've been up against some other major movies. We delivered in October. The film gets released in November and therefore has clear sailing all the way until next summer, which drives the movie to the number one box office hit of all time. Missing the original date benefited him and 20th Century Fox, but it didn't benefit us. We wound up hurt financially, and our reputation suffered as well.

On the heels of Titanic Cameron decided Digital Domain needed a new CEO. He didn't feel that I was capable of running the company, so he wanted to turn our operating committee into the CEO: he would be the C, Stan would be the E, and I would be the $\mathrm{O}$. He also wanted us to hire a president, so I started a worldwide search and interviewed half a dozen possible candidates. While this worldwide search is under way, a board meeting is scheduled at which we review the financials, which were terrible because of Titanic, and then I tell the board, "By the way, the operating committee is searching for a president."

The Cox and IBM directors are shocked. They ask Jim, chairman of the board, to explain why the company needs to hire a new president. Jim says, "We don't think Scott is capable." And the board responds, "Bullshit! Not only do we back Scott as the CEO, but your services agreement is done and we want you to resign. Scott's the chairman, Scott's the CEO, and that's the way it's going to be." At which point Jim grabs his jacket, throws it over his shoulder, and as he's leaving, he turns around to quote a line from Titanic: "Gentlemen, it's indeed been an honor and privilege playing with you." Then walks out and I don't see him again until Stan Winston's funeral, many years later.

The story explains so much about the extraordinary challenges confronting VFX shops.

The VFX business model has never worked. People start to say, "In the good old days," and my response is, "No, there were never any 'good old' days." The good old days are the bad old days. And today is just as bad. It was never good. You barely eked out a profit or a loss and you never showed a return on equity to your investors. It was never an environment that was profitable. You worked really hard and for really long hours to create some of the greatest images known to humankind and you got nothing for it, from a financial point of 
view. Those were the old days. Now today, when you add the subsidies to the picture, it's disastrous.

At the time, did you have any premonition as to where things were headed?

Yes, without a doubt. Around 1994 I tried to start a trade association. I called it AVEC, the French word for "with," the Association of Visual Effects Creators. I wanted to get the major players in the visual effects industry together to form a trade association and change the business model. It didn't work.

Why?

The folks who run these companies are not businesspeople, and because they're not businesspeople, they're all scared to death. It goes back to that line that George Lucas has about the crews who worked on Star Wars, which was, "If you give 'em enough beer and pizza, they'll do anything!" And so you have these fanboys (and now fangirls) who are prepared to offer whatever it takes because they get to see their names in the credits of Star Wars.

But wouldn't it be in their interest to form a trade association?

Think about Pepsi and Coke. They're selling sugar water that sort of tastes the same and looks exactly alike. Talk about rivalry! And yet they have a trade association. Automakers. General Motors versus Ford. Again, rivalry! But they have a trade association. The motion picture industry: Paramount versus Disney! They have a trade association. So if you approach business like business, you understand, "Okay, guys. We all know that we are incredibly competitive and frankly don't trust each other at all-but the problem is not us. The problem is the clients and the business model. We're starving and doing all the work and they're making billions of dollars. They're the fat cats. Let's get together here and stop this stuff!" But to date, there still isn't a trade association. Given that six major Hollywood studios control the biggest feature films, all the VFX companies are too afraid.

You mentioned the artists who are willing to work for beer and pizza, but are you also saying that the people who are running the shops lack an industrial mentality? Would that include John Hughes, for example, of Rhythm \& Hues?

John Hughes is not much of a businessman. He is an incredible human being and cares about his people and works really hard and is very, very smart. But he has a serf mentality, which is, "I am not worthy! Okay, we'll do it for \$1.98, please don’t 
hit me!" He's scared to death of the major studios. Even near the end, when his company was on the verge of bankruptcy, his response to me was, "I'll consider a trade association, but only if everybody else joins. And don't use my name.”

\section{And that's the common response?}

Well, things have changed now. John Hughes and Scott Ross were the last of a dying breed of owner-operators. Nowadays the people who run the major facilities are not the owners. They are salaried. From their perspective, why would they want to rock the boat? They're figuring they're going to be fired in a couple of years anyway because they couldn't make the company profitable. Why should they be mavericks and try to do something that involves a long-term plan? They're thinking: "I should make as much money as I can in the shortest period of time."

\section{What is the root of their fear?}

The fear is that there is only so much food brought to the table and if I don't kiss the ass of the person who is bringing the food, I won't get my share and I'll starve to death. Remember, there are only six clients!

This sounds like a nightmare for VFX companies. What's left in Los Angeles? Rhythm \& Hues went bankrupt; so did Digital Domain and dozens of others.

Look, subsidies don't talk, they scream. From a studio's perspective, they're going to go wherever the subsidies are the highest. From a visual effects facility's perspective, they're scared to do anything but follow the subsidies. So if the studio tells me, "I'll give you the job if you move to Vancouver," I'm moving to Vancouver. And then when all of a sudden Montreal offers a better deal than Vancouver and the studio says, "I'd love to give you the work because we have a relationship, but ..." the studio knows full well that you're going to Montreal. There's no doubt about it. From a studio's perspective, everything works perfectly.

By the way, the interesting thing is that about five years ago people were saying China and India were going to eat our shorts. That hasn't happened, and the reason why is because I can go to London and get better prices [due to government subsidies] than I can in Mumbai.

It sounds like an ideal world from a producer's perspective. But doesn't it undermine a VFX company's ability to bring together talent? Or are people so mobile at this point that you can pull together talent regardless of location?

VFX companies need to hold onto their core talent. The teams that make major motion pictures today are comprised of about five hundred people. Of that team, 
maybe a hundred and fifty are critical. So you want to hold onto those, but the rest you just hire. It's like, "Would you like to spend the next two years working on Star Wars and living in London?" The people who are starving to death because there's no work in Los Angeles say, "I'd rather not, but sure! Let's go! I'll pack some clothes and some toothpaste and I'll be okay."

How about the shops in Canada or the United Kingdom, where they benefit from subsidies?

When the subsidies happen, the visual effects company sees none of it. The good news is that if you're in London and you qualify for the subsidies, you get the job. The bad news is, you get the job. It's not like the studios are giving a portion of the subsidy back to the visual effects company-they're keeping the subsidy and still using their leverage to lower the rates they pay to the VFX shops.

Visual effects companies are not making do. They're losing money. So how do they survive? Volume! Nobody's making any money, but if you manage your cash flow correctly and keep your labor costs under control, you can keep going. Why do all of these issues fall on the shoulders of the artists? Because that's the biggest cost of your show. If I'm a facilities general manager, where am I going to cut corners? I could stop serving donuts, but, really, what does that do? Instead they say, "Let's not pay them overtime. How about their medical? Let's cut back on their medical. Let's do everything we can to cut corners." Meanwhile the artists are under the false impression that managers are doing it to make a fortune. Not true! They're doing it so they can stay in business. There's only one group that's making a fortune, and that's the motion picture studios.

\section{Do you think the subsidy game will end up hurting the studios in the long run?}

No. Listen, when the sun shines, the sun shines and you take it as you can. I think the studios are run by extremely good businesspeople and they're going to let this run as long and as hard and as fast as it possibly can. They'll take the subsidies while they last and they'll develop contingency plans.

If I were a studio executive, I would do everything I possibly could to make the major VFX companies open up shops in places like India and China. I know that today I can't do Avatar (2009) in India, but if Weta opens up a shop in India, or if Weta hires and trains enough Indian workers, you take a couple of cranks of the wheel and all of a sudden you have what you need in India. And then you don't need subsidies, because the cost of living there is considerably less.

If I were a VFX artist, the first thing I'd do is look for work elsewhere. I'd look for work outside of the motion picture industry. Or if I'm really creative, I would start making my own product. And if I'm both, I would work outside of the movie industry and I'd try making my own product. 
Is there anything that can be done to put an end to the subsidy game?

In the best of all worlds, an international guild would be great. You take all the people who are working as digital artists or digital manufacturers in the visual effects, animation, television, and gaming industries, and you form a guild that operates as a negotiating platform against and with producers. But there are so many reasons why it doesn't work and why it might not work. The people in the subsidized locales are as happy as pigs in shit-today, at least. They don't see what the future looks like. They're only focused on what's happening today. Therefore, anybody who speaks out against subsidies is their enemy. If you're a working professional in Vancouver and somebody says, "Subsidies are terrible," you're up on your heels and ready for fisticuffs. "Subsidies aren't terrible. My kid goes to school because of subsidies. I'm going to do whatever I can to fight for them." The distrust and warfare among digital artists is such that I don't see hope for a guild, particularly not on an international level. As for the traditional unions like IATSE and the IBEW [International Brotherhood of Electrical Workers], they have the wrong profile for these men and women, so they're immediately mistrusted.

Why do they have the wrong profile?

First of all, most of the people working in the digital, visual effects, and animation world have advanced degrees and are stereotypical nerds. The people who run IATSE look and feel a whole lot more like the teamsters. They don't look like the sorts of folks who might represent these white-collar, advanced-degree, pseudointellectual artists who are twenty-five to thirty-five years old, listening to Sublime, and have tattoos all over their bodies. It's a cultural disconnect between your father's union and you. It's an uphill battle.

\section{No hope at all?}

Let me tell you why I think a union wouldn't work. Unions are not international, by their very nature. So let's assume that IATSE could get enough workers to sign cards here in Los Angeles and that those cards allowed certain jobs to become unionized. Most of those shops already have international locations where most of their work is now going.

The cost of working with a union shop is higher than the cost of working with a nonunion shop. I don't care what anybody in the union says, it is! I sat on the board of trustees of a union, and I've run a nonunion company. Running a union company costs more money than running a nonunion company. And if it costs more money, who is going to pay that? The studios' sole interest is to keep costs 
down. So if I run a union company, I'm going to come in with a higher bid, which gives more impetus for the studio to contract with a facility in India or the Philippines where there isn't a union, or in Vancouver or London, where unions offer more concessions and benefit from subsidies.

If you had an international association of workers, and all the workers in all of the major shops agreed on it, now that's a possibility. But the reality of organizing that sounds overwhelming to me. We don't even have a union here, and the artists in Vancouver are arguing with the artists in Montreal, who are arguing with the artists in London. They're all at each other's throats. Why? You'll hear, "Why should I rock the boat, I work in Vancouver. I get subsidies, why should I go against subsidies?"

The only reason you're in Vancouver now is because that's where the work is. So if you want to become a gypsy, migrant, digital-labor worker, yeah, then be in favor of subsidies. You'll spend nine months in Mumbai, nine months in Shanghai, nine months in Beijing. Wherever you have to go. And maybe at age twenty-five that's not so bad. But at age forty-five, it sucks. Still, they're not interested in unions.

Do you think they would be if times were different? For example, the reason guilds and unions emerged in Hollywood was in part because of a New Deal consciousness.

Yes, it was the zeitgeist of the 1930s and 1940s that allowed unions to come into play.

\section{Do you think we're headed for another moment like that?}

No, I don't. I wish we were, but no. And the reason is, it's a different world. It's now globalized. It's no longer about protecting the workers of Detroit or protecting the migrant farmworker. Now it's, "How do you deal with China?"

\section{Artists are getting screwed in China, too.}

Maybe over time we'll see it, but not as long as there's fear among the workers and not enough rice on the table. I don't see it as an immediate fix. Can you imagine what would happen if even four of the top VFX companies told the studios, "We're no longer going to work under the current business model of fixed-price bids. The new business model is going to be time and materials. We're going to charge you cost plus markup. And we want to participate in the back-end royalties. And it's going to save you money! Here are all of the reasons why." What would the studios do? It would be a different world.

By the way, that's how other parts of the production process work. There's a producer and an assistant director, and you know that if you put in ten hours on the set and then decide you need three more hours on that set, at the end of the 
day the accountants are going, "Jesus, that ran $\$ 130,000$ dollars over budget. We have to make that up." Not with visual effects! It's not the studios' problem, it's the visual effects company's problem.

If a trade association won't work and a union won't work, are there any other possibilities?

There's one other pipe dream that could be interesting. All of the companies that we're talking about, those in the top ten, none of them are making any money. They're all in the shitter. Well, if four of us got together and we put together a halfbillion dollars, we could do a roll-up and buy another five or six. At that point we'd control the movie industry. "New Co." is now setting the prices. You want your stuff done? You've got to go through us. It would make the days of Michael Ovitz and CAA look like a walk in the park because every major movie-I think it's forty-nine of the top fifty movies of all time-are visual effects movies. Talk about power.

Why doesn't anybody do that?

Nobody has the guts.

What are the top ten facilities right now?

ILM, Sony Pictures Imageworks, Digital Domain, Weta, Method, Double Negative, Framestore, Pixomondo, and Prime Focus World. A few years ago I would've put Rhythm \& Hues on there, too.

Walk us through this. How would this scenario work?

Step one, you do a roll-up. You buy up the companies and lock in the top talent. Once you're consolidated, you have economies of scale. Then you install good management, because a lot of these companies don't have good management. With really good management and economies of scale, you bring your costs down. Then you go back and renegotiate your deals with the studios. Now you've become a major broker in Hollywood. It's all about negotiating leverage and controlling the available pool of talent, because in the end, the very biggest studio feature films depend on world-class visual effects. 